\title{
ANALISIS MODEL EPIDEMIK SVEIR DENGAN CONTINUOUS TIME MARKOV CHAIN (CTMC) PADA PENYAKIT RUBELLA
}

\section{Analysis of SVEIR's Epidemic Model with Continuous Time Markov Chain (CTMC) in Rubella Disease}

\author{
Nur Eliska $^{1 *}$, Hadi Sumarno ${ }^{2}$, Paian Sianturi $^{3}$ \\ ${ }^{1,2,3}$ Prodi Matematika Terapan, FMIPA, Institut Pertanian Bogor \\ Jln. Raya Darmaga, Kota Bogor, 16680, Indonesia \\ Corresponding authore-mail: ${ }^{*}$ eliska_n@apps.ipb.ac.id
}

\begin{abstract}
Abstrak
Penyakit rubella yang dikenal dengan sebutan campak Jerman adalah penyakit menular yang disebabkan oleh virus rubella. Penelitian ini mempelajari model dinamika penyebaran penyakit rubella menggunakan model SVEIR yang merupakan modifikasi dari model yang dikembangkan oleh Beraud dan Saito, dengan pendekatan stokastik CTMC. Simulasi dilakukan untuk mengamati pengaruh perubahan: nilai awal, laju infeksi $(\gamma)$, tingkat efektivitas vaksin $(\varepsilon)$, dan laju vaksinasi $(c)$. Berdasarkan hasil simulasi diperoleh bahwa, perubahan nilai awal mempengaruhi peluang terjadinya wabah. Semakin tinggi laju sembuh dapat menurunkan peluang wabah. Sedangkan semakin tinggi tingkat efektivitas vaksin dan laju vaksinasi menyebabkan nilai $R_{0}$ semakin rendah serta nilai peluang wabah yang cukup kecil; artinya peluang bebas penyakit semakin besar dan menghilangnya penyakit rubella dari sistem.
\end{abstract}

Kata Kunci : Rubella, vaksinasi, bilangan reproduksi dasar.

\begin{abstract}
Rubella disease, widely known as German measles is a contagious disease caused by the rubella virus. This study studied the dynamics of the rubella disease using the SVEIR model. This model was developed by Beraud and Saito, which was further implemented within a stochastic CTMC approach. Simulations were carried out to examine the effect changing: initial values, infection rate $(\gamma)$, effectiveness of vaccine $(\varepsilon)$, and rate of vaccination $(c)$. Based on simulation results, it was found that changes of initial value would alter the probability of disease outbreak. But, the higher of recovery rate would decrease the probability of outbreak. Meanwhile, the higher the both level of effectiveness and rate of vaccination would contribute to decrease the reproduction number $R_{0}$. As a consequense, the rubella disease would gradually vanish within the system.
\end{abstract}

Keywords: Rubella, vaccination, basic reproduction number.

Article info:

Submitted: $14^{\text {th }}$ July $2021 \quad$ Accepted: $30^{\text {th }}$ August 2021

How to cite this article:

N. Eliska, H. Sumarno, and P. Sianturi, “ANALISIS MODEL EPIDEMIK SVEIR DENGAN CONTINUOUS TIME MARKOV CHAIN (CTMC) PADA PENYAKIT RUBELLA”, BAREKENG: J. Il. Mat. \& Ter., vol. 15, no. 03, pp. 591-600, Sep. 2021. 


\section{PENDAHULUAN}

Penyakit Rubella adalah penyakit menular yang disebabkan oleh virus Rubella dengan genus rubivirus [1]. Penyakit Rubella ini juga dikenal sebagai campak Jerman yang membuat penderitanya mengalami demam dengan suhu hampir mencapai $39^{\circ} \mathrm{C}$, terdapat bercak merah/ rash makulopapuler disertai pembesaran kelenjar limfe di belakang telinga, leher belakang (sub occipital) [2]. Rubella adalah infeksi virus yang menyebar di droplet udara. Penyakit ini juga dapat menyebar melalui kontak langsung dengan peralatan yang digunakan penderita misalnya, alat bantu pernafasan bahkan hanya sekedar sentuhan.

Penyakit Rubella merupakan penyakit yang sangat berbahaya, khususnya untuk ibu hamil pada trimester pertama yang berdampak keguguran, kematian janin atau Sindrom Rubella Kongenital (Congenital Rubella Syndrome/ CRS) pada bayi yang dilahirkan, indikasi penyakit yang dialami bayi seperti kelainan jantung, katarak mata, bintik-bintik kemerahan (Purpura), microcephaly (kepala kecil) dan tuli [3]. Adapun jumlah total kasus terjangkit Rubella di Indonesia yang dilaporkan pada tahun 2014 sampai dengan tahun 2018 mencapai 5.737 orang [4]. Artinya, pada penyakit Rubella perlu diperhatikan lebih serius untuk meminimalisir penyakit tersebut. Dalam hal ini, perlu adanya model matematika untuk dapat menganalisis perilaku atau dinamika penyebaran penyakit tersebut.

Model matematika penyebaran penyakit Rubella telah dilakukan oleh beberapa ahli, diantaranya adalah Guillaume Beraud, sebagaimana penelitiannya menggunakan model penyebaran penyakit Rubella tipe SIR, dengan populasi yang terbagi menjadi tiga kompartemen, yaitu rentan (Susceptible), terinfeksi (Infected) serta kebal/ sembuh terhadap penyakit (Recovered) [4]. Kemudian model tersebut diperluas oleh Masaya M. Saito et.al menjadi tipe SVIR, dengan adanya populasi yang divaksinasi (vaccination) [5]. Dalam kedua penelitian tersebut digunakan pendekatan model deterministik. Pada penelitian ini akan membahas model penyebaran penyakit Rubella dengan menambahkan populasi terekspos (SVEIR) dengan pendekatan continuous-time Markov Chain (CTMC). Dengan demikian, adapun tujuan yang akan dicapai pada penelitian ini yaitu, mengkonstruksi ulang model epidemik SVEIR stokastik menggunakan continuous-time Markov Chain (CTMC, menentukan peluang transisi penyebaran penyakit, menentukan peluang terjadinya wabah penyakit, dan melakukan simulasi numerik untuk mengetahui pengaruh perubahan nilai parameter terhadap sistem dinamika penyakit Rubella.

\section{METODE PENELITIAN}

Penelitian ini mengkonstruksi ulang model yang dibentuk oleh Guillaume Beraud Beraud dan M. Saito et.al yang menggunakan pendekatan model deterministik menjadi pendekatan stokastik dengan menggunakan rantai Markov waktu kontinu (CTMC). Pada model ini diberikan adanya populasi terekspos (Exposed), dengan terdapat masa inkubasi yang telah ditentukan, yaitu 14-21 hari [6]. Kemudian menentukan titik tetap tanpa penyakit dari sistem, melakukan pembentukan model stokastik CTMC di antaranya penentuan peluang transisi dan peluang wabah. Setelah itu melakukan simulasi numerik untuk melihat perilaku sistem dengan membuat beberapa skenario, yaitu dengan memberikan keberagaman nilai parameter model, sehingga dapat melihat perubahan perilaku yang terjadi di dalam sistem. Selanjutnya menentukan hasil yang diperoleh di dalam penelitian ini di antaranya (1) melakukan penurunan rumus agar populasi pada sistem menjad konstan, (2) menentukan titik tetap bebas penyakit, (3) model stokastik epidemik SVEIR pada penyebaran penyakit Rubella, dan (4) simulasi numerik untuk melihat dinamika populasi yang disebabkan oleh memvariasikan nilai $I(0)$ yaitu dengan memvariasikan nilai awal pada populasi terinfeksi sampai dengan menghasilkan bebas penyakit, $\gamma$ (laju masa penjangkitan dari individu yang terinfeksi menjadi bebas penyakit), $\varepsilon$ (laju vaksinasi secara efektif) dan $c$ (laju vaksinasi).

\section{HASIL DAN PEMBAHASAN}

Pada penelitian ini, model SVEIR yang diberikan akan dilakukan simulasi numerik dengan berdasarkan beberapa definisi dan menggunakan software R, sebagai berikut:

\section{Definisi 1. Proses stokastik}

Proses stokastik $X=\{X(t), t \in T\}$ adalah suatu himpunan dari variabel acak (random variables) yang memetakan suatu ruang contoh (sample space) $\Omega$ ke suatu ruang state (state space) $S$ [7]. 


\section{Definisi 2. Proses Stokastik Waktu Kontinu}

Suatu proses stokastik $X$ disebut proses stokastik dengan waktu kontinu jika $T$ kontinu dengan $X=$ $\{X(t), t \geq 0\}[8]$.

\section{Definisi 3. Proses Markov}

Proses Markov adalah proses stokastik dimana kejadian yang akan datang dari suatu sistem hanya bergantung pada waktu yang sedang terjadi dan tidak bergantung pada waktu lampau. Proses stokastik $\{X(t): t \in[0 ; \infty)\}$, disebut continuous-time Markov chain (CTMC) jika memenuhi kondisi berikut [9]. Untuk sebarang bilangan real yang memenuhi $0 \leq t_{0} \leq t_{1} \leq \cdots \leq t_{n} \leq t_{n+1}, P\left\{X\left(t_{n+1}\right)=i_{n+1} \mid X\left(t_{0}\right)=i_{0}, X\left(t_{1}\right)=i_{1}, \ldots, X\left(t_{n}\right)=\right.$ $\left.i_{n}\right\}=P\left\{X\left(t_{n+1}\right)=i_{n+1} \mid X\left(t_{n}\right)=i_{n}\right\}$.

\section{Definisi 4. Bilangan Reproduksi Dasar}

Bilangan reproduksi dasar merupakan nilai harapan terjadinya infeksi setiap satuan waktu. Infeksi ini terjadi pada suatu populasi rentan yang dihasilkan oleh satu individu yang sudah terinfeksi, dinotasikan dengan $\mathcal{R}_{0}$ [10]. Dalam penelitian ini, untuk menentukan $\mathcal{R}_{0}$ digunakan metode yang dikenalkan oleh Van Den Driessche dan Watmough, yaitu dengan mengkonstruksi suatu matriks yang berasal dari sub-sub populasi yang menyebabkan infeksi. Matriks tersebut dikenal dengan the next generation matrix. Nilai $\mathcal{R}_{0}$ merupakan nilai eigen tak negatif terbesar dari matriks ini.

Kondisi yang memungkinkan dari bilangan reproduksi dasar menurut Driessche dan Watmough adalah

1. Jika $\mathcal{R}_{0}<1$ maka jumlah individu yang terinfeksi berkurang pada setiap generasi, artinya penyakit ini tidak akan menyebar.

2. Jika $\mathcal{R}_{0}>1$ maka jumlah individu yang terinfeksi meningkat pada setiap generasi, artinya penyakit akan menyebar.

The next generation matrix, mempunyai dua bagian yaitu $F$ dan $V^{-1}$ yang didefinisikan sebagai:

$$
G=F V^{-1}
$$

Dengan $F$ dan $V$ adalah matriks-matriks yang berukuran $n \times n$, yaitu;

$$
F=\frac{\partial F_{i}}{\partial a_{i}}\left(b_{0}\right), \operatorname{dan} V=\frac{\partial V_{i}}{\partial a_{i}}\left(b_{0}\right)
$$

Dengan $\left(b_{0}\right)$ adalah titik tetap bebas penyakit. Notasi $F_{i}$ adalah fungsi yang menunjukkan kemunculan infeksi baru dikompartemen $i, V_{i}$ adalah fungsi yang menunjukkan transfer infeksi dari satu kompartemen $i$ ke kompartemen lain. Menurut Van Den Driessche dan Watmough diperoleh;

$$
\mathcal{R}_{0}=\rho\left(F V^{-1}\right)
$$

Dengan $\rho\left(F V^{-1}\right)$ adalah maksimum dari modulus nilai-nilai eigen dari $G=F V^{-1}$.

\section{Definisi 5. Proses Bercabang Multitype}

Tiga asumsi dasar definisi proses bercabang Galton-Watson adalah sebagai berikut:

1. Untuk setiap individu dalam generasi $n$ yang memberikan kelahiran atau keturunan $Y n$ dalam generasi selanjutnya, di mana $Y_{n}$ adalah variabel acak yang nilainya $\{0,1,2, \ldots\}$ dengan distribusi keturunannya adalah $\left\{p_{k}\right\}_{k=0}^{\infty}$ di mana,

$$
P\left\{Y_{n}=k\right\}=p_{k}, k=0,1,2,3, \cdots .
$$

2. Untuk setiap individu memberikan kelahiran yang saling bebas dari semua individu yang lain.

3. Distribusi keturunan yang sama untuk semua generasi $n$ adalah $Y_{n}=Y$ [8].

Untuk menentukan proses bercabang, dimisalkan $\{\boldsymbol{I}(t): t \in[0, \infty)\}$ adalah koleksi vektor variabel acak diskret, $\boldsymbol{I}(t)=\left(I_{1}(t), \ldots, I_{n}(t)\right)^{t}$, dimana $t$ adalah transpose matrix. Berdasarkan hal tersebut, diasumsikan bahwa individu tipe $i$ memberikan kelahiran individu tipe $j$ dan jumlah keturunan yang dihasilkan tipe $i$ tidak bergantung pada jumlah keturunan yang dihasilkan oleh individu lain pada tipe $i$ atau tipe $j, \operatorname{dan} j \neq i$. Selain itu, individu tipe $i$ memiliki keturunan dengan sebaran peluang yang sama. Misalkan $\left\{Y_{j i}\right\}_{j=1}^{n}$ adalah variabel 
acak keturunan untuk tipe $i, i=1,2, \ldots, n$ sehingga $Y_{j i}$ adalah jumlah keturunan tipe $j$ yang dihasilkan oleh tipe $i$. Probabilitas satu individu tipe $i$ melahirkan $k_{j}$ individu tipe $j$ adalah

$$
P_{i}\left(k_{1}, k_{2}, \ldots, k_{n}\right)=P\left(Y_{1 i}=k_{1}, \ldots, Y_{n i}=k_{n}\right) .
$$

Selanjutnya probability generating function (pgf) keturunan tipe $i$ dengan memerikan $I_{i}(0)=1$, dan $I_{j}(0)=$ $0, j \neq i$, didefinisikan dengan,

$$
f_{i}\left(u_{1}, \ldots, u_{n}\right)=\sum_{k_{n}=0}^{\infty} \ldots \sum_{k_{1}=0}^{\infty} P_{i}\left(k_{1}, k_{2}, \ldots, k_{n}\right) u_{1}^{k_{1}} \ldots u_{n}^{k_{n}},
$$

$\operatorname{dimana} f_{i}(1, \ldots, 1)=1$.

Definisi 6. Sistem Persamaan Diferensial

Sistem persamaan diferensial ordo satu dengan $n$ persamaan dan $n$ buah fungsi yang tak diketahui $x_{1}, x_{2}, \ldots, x_{n}$ dapat ditulis sebagai berikut:

$\dot{x}(t)=f(x(t), t)$, dengan $x=\left(\begin{array}{c}x_{1} \\ \vdots \\ x_{n}\end{array}\right), f(x)=\left(\begin{array}{c}f_{1}(x(t)) \\ \vdots \\ f_{n}(x(t))\end{array}\right)$.

Menurut Tu jika sistem persamaan diferensial tidak bergantung secara eksplisit pada $t$ maka disebut persamaan diferensial mandiri yang ditulis sebagai berikut:

$\dot{x}(t)=f(x)[11]$.

\section{Definisi 7. Titik Tetap}

Misalkan diberikan sistem persamaan diferensial sebagai berikut:

$$
\dot{x}(t)=f(x) .
$$

Titik $x^{*}$ disebut titik tetap atau titik kritis jika memenuhi $f\left(x^{*}\right)=0[11]$.

\subsection{Model SVEIR Pada Penyakit Rubella}

Pada model SVEIR dengan bagan alur skematik yang berdasarkan model SIR (Susceptible, Infected, Recovered) oleh Beraud[12] dan model SVIR (Susceptible, Vaccinated, Infected, Recovered) oleh Saito et.al [5], serta dengan menambahkan kompartemen populasi E (Exposed)[6], sebagai berikut:

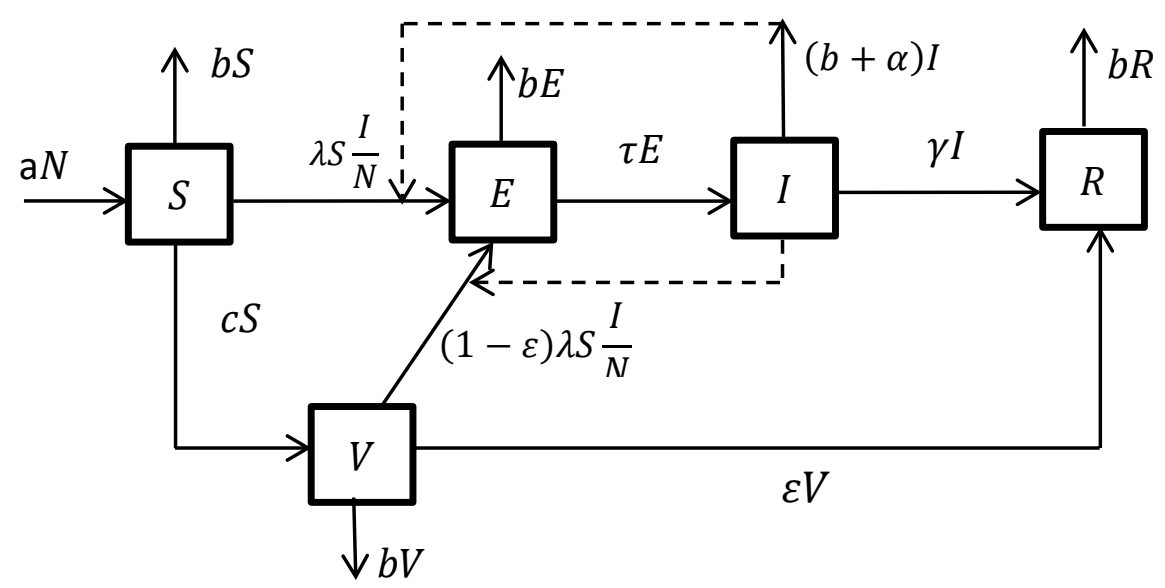

Gambar 1. Diagram modifikasi kompartemen model SVEIR

$$
\text { Keterangan : } \begin{aligned}
-\rightarrow & : \text { Proses transmisi } \\
& : \text { : Pusceptible. } \\
V & : \text { Vaccinated. } \\
E & : \text { Exposed. }
\end{aligned}
$$

$I$ : Infected.

$R:$ Recovered. 
Hubungan proses transmisi dan pengaruh antar kompartemen seperti pada Gambar 1, dapat dinyatakan dalam bentuk sistem persamaan diferensial sebagai berikut:

$$
\begin{aligned}
& \frac{d S}{d t}=\mathrm{a} N-b S-\lambda S \frac{I}{N}-c S \\
& \frac{d V}{d t}=c S-b V-(1-\varepsilon) \lambda S \frac{I}{N}-\varepsilon V \\
& \frac{d E}{d t}=\lambda S \frac{I}{N}+(1-\varepsilon) \lambda V \frac{I}{N}-b E-\tau E \\
& \frac{d I}{d t}=\tau E-(b+\alpha+\gamma) I \\
& \frac{d R}{d t}=\gamma I+\varepsilon V-b R
\end{aligned}
$$

dengan $a, b, c, \lambda, \alpha, \gamma, \epsilon, \tau$ menyatakan parameter model.

\subsection{Model Stokastik Epidemik SVEIR}

Dalam rangka mengkonstruksi model stokastik, perlu ditetapkan himpunan variabel yang digunakan dalam model CTMC. Seperti dapat dilihat pada Gambar 1, terdapat 5 variabel yaitu $S, V, E, I$, dan $R$. Namum dengan mengasusikan bahwa populasi konstan, artinya $N(t)=N$ untuk semua $t$, maka terdapat satu variabel yang tidak bebas, yaitu $R(t)=N-S(t)-V(t)-E(t)-I(t)$. Selanjutnya himpunan dari keempat variabel $\{S(t), V(t), E(t), I(t)\}$ diasumsikan memenuhi sifat Markov yaitu [7]:

$$
\begin{aligned}
& P\{S(t+\Delta t), V(t+\Delta t), E(t+\Delta t), I(t+\Delta t) \mid(S(0), V(0), E(0), I(0)) \\
& (S(\Delta t), V(\Delta t), E(\Delta t), I(\Delta t)), \ldots,(S(t), V(t), E(t), I(t))\}= \\
& P\{S(t+\Delta t), V(t+\Delta t), E(t+\Delta t), I(t+\Delta t) \mid(S(t), V(t), E(t), I(t))\}
\end{aligned}
$$

Dengan membuat pemisalan $(S(t), V(t), E(t), I(t))=(a, b, c, d)$ dan $(S(t+\Delta t), V(t+\Delta t), E(t+$ $\Delta t), I(t+\Delta t))=(i, j, k, l)$ maka perpindahan dari state $(a, b, c, d)$ ke state $(i, j, k, l)$ dapat dinyatakan sebagai berikut:

$$
\begin{aligned}
P_{(a, b, c, d),(i, j, k, l)}(t, t+\Delta t) & =P\{S(t+\Delta t)=i, V(t+\Delta t)=j, E(t+\Delta t)=k, \\
I(t+\Delta t) & =1 \mid S(t)=a, V(t)=b, E(t)=c, I(t)=\mathrm{d}\}
\end{aligned}
$$

Sehingga peluang transisi $P$ dapat dituliskan sebagai berikut:

$$
P= \begin{cases}(\mathrm{aN}) \Delta t+o(\Delta t), & (i, j, k, l)=(a+1, b, c, d) \\ (b S) \Delta t+o(\Delta t), & (i, j, k, l)=(a-1, b, c, d) \\ \left(\lambda S \frac{I}{N}\right) \Delta t+o(\Delta t), & (i, j, k, l)=(a-1, b, c+1, d) \\ \Delta t+o(\Delta t), & (i, j, k, l)=(a, b, c-1, d) \\ (\tau E) \Delta t+o(\Delta t), & (i, j, k, l)=(a, b, c-1, d+1) \\ ((b+\alpha+\gamma) I) \Delta t+o(\Delta t), & (i, j, k, l)=(a, b, c, d-1) \\ (c S) \Delta t+o(\Delta t), & (i, j, k, l)=(a-1, b+1, c, d) \\ (b V) \Delta t+o(\Delta t), & (i, j, k, l)=(a, b-1, c, d) \\ \left((1-\varepsilon) \lambda V \frac{I}{N}+\varepsilon V\right) \Delta t+o(\Delta t), & (i, j, k, l)=(a, b-1, c+1, d) \\ 1-Y(t) \Delta t+o(\Delta t), & (i, j, k, l)=(a, b, c, d) \\ o(\Delta t), & \text { yang lainnya }\end{cases}
$$

dimana,

$$
Y(t)=\mathrm{aN}+b S+\lambda S \frac{I}{N}+b E+\tau E+(b+\alpha+\gamma) I+c S+b V+(1-\varepsilon) \lambda V \frac{I}{N}+\varepsilon V
$$

\subsection{Peluang Wabah}

Peluang wabah dapat ditentukan dengan[13]:

$$
1-P(I(t)=0)= \begin{cases}0, & \mathcal{R}_{0} \leq 1 \\ 1-q_{1}^{i} q_{2}^{e}, & \mathcal{R}_{0}>1,\end{cases}
$$


dengan $P(I(t)=0)$ adalah peluang bebas penyakit.

Selanjutnya untuk menghitung nilai $q_{1}$ dan $q_{2}$ diperlukan informasi tentang bilangan reproduksi dasar $\left(\mathcal{R}_{0}\right)$. Bilangan reproduksi dasar dapat diperoleh menggunakan the next generation matrix, sehingga diperoleh matriks $F$ dan $V$, sebagai berikut:

$$
\begin{gathered}
F=\left(\begin{array}{cc}
0 & \frac{\mathrm{Sr} \lambda}{\mathrm{Nr}}+\frac{\operatorname{Vr}(1-\varepsilon) \lambda}{\mathrm{Nr}} \\
0 & 0
\end{array}\right) \\
V=\left(\begin{array}{cc}
b+\tau & 0 \\
-\tau & b+\alpha+\gamma
\end{array}\right)
\end{gathered}
$$

Berdasarkan pendekatan Van Den Driessche dan Watmough, bilangan reproduksi dasar $\mathcal{R}_{0}$ diperoleh:

$$
R_{0}=\frac{a(b+c+\varepsilon-c \varepsilon) \lambda \tau}{(b+c)(b+\alpha+\gamma)(b+\varepsilon)(b+\tau)}
$$

Selanjutnya, penentuan $q_{1}^{i} q_{2}^{e}$ menggunakan probability generating function (pgf) dengan proses bercabang berganda [13]. Dalam model ini terdapat dua variabel yang dapat menyebabkan infeksi, yaitu $I$ dan $E$. Dengan menetapkan $I(0)=0$, dan $E(0)=1$ diperoleh pgf untuk $E$ yaitu:

$$
f_{1}\left(u_{1}, u_{2}\right)=\frac{\tau u_{2}+b}{\tau+b}
$$

dan dengan menetapkan $I(0)=1$, dan $E(0)=0$ diperoleh pgf untuk $I$ yaitu:

$$
f_{2}\left(u_{1}, u_{2}\right)=\frac{(\lambda+(1-\varepsilon) \lambda) u_{1} u_{2}+b+\alpha+\gamma}{\lambda+(1-\varepsilon) \lambda+b+\alpha+\gamma}
$$

Selanjutnya nilai $q_{1}$ dan $q_{2}$ diperoleh dengan menetapkan suatu kondisi bahwa untuk $0<q_{i}<1$, terdapat $f_{i}\left(q_{1}, q_{2}\right)=q_{i}$, yaitu $f_{1}\left(q_{1}, q_{2}\right)=q_{1}$ dan $f_{2}\left(q_{1}, q_{2}\right)=q_{2}$, dan dihasilkan nilai

$$
q_{1}{ }^{i} q_{2}{ }^{e}=\left(\frac{(b)(\lambda+(1-\varepsilon) \lambda+b+\alpha+\gamma)}{(\tau+b)(\lambda+(1-\varepsilon) \lambda)}\right)^{i}\left(\frac{(b+\alpha+\gamma)(\tau+b)}{(\tau)(\lambda+(1-\varepsilon) \lambda+b+\alpha+\gamma)}\right)^{e} .
$$

\subsection{Simulasi Numerik}

Simulasi numerik dilakukan untuk mempelajari pengaruh perubahan parameter terhadap perilaku penyebaran penyakit rubella. Simulasi numerik dilakukan dengan mengkondisikan terjadi wabah $\left(\mathcal{R}_{0}>1\right)$ dan bebas penyakit $\left(\mathcal{R}_{0}<1\right)$, dengan memberikan variasi pada parameter-parameter $I(0), \gamma, \varepsilon$ dan $c$. Tabel 1 berikut menyajikan nilai awal parameter yang digunakan.

Tabel 1 Nilai Parameter

\begin{tabular}{clccc}
\hline Parameter & \multicolumn{1}{c}{ Deskripsi } & Nilai & Satuan & Sumber \\
\hline$N$ & Total populasi & 120.000 .000 & orang & {$[5]$} \\
\hline $\mathrm{a}$ & Laju kelahiran secara alami & 0,02 & $1 /$ tahun & {$[12]$} \\
\hline$\alpha$ & $\begin{array}{l}\text { Laju kematian karena infeksi } \\
\text { penyakit }\end{array}$ & 0.01 & $1 /$ tahun & {$[6]$} \\
\hline$\lambda$ & $\begin{array}{l}\text { Laju penularan akibat kontak } \\
\text { dengan populasi terinfeksi }\end{array}$ & $365 / 5$ & $1 /$ tahun & {$[14]$} \\
\hline$\gamma$ & $\begin{array}{l}\text { Laju masa penjangkitan dari } \\
\text { individu yang terinfeksi } \\
\text { menjadi bebas penyakit }\end{array}$ & $365 / 7$ & $1 /$ tahun & {$[15]$} \\
\hline$\tau$ & Laju masa inkubasi & $365 / 21$ & $1 /$ tahun & {$[6]$} \\
\hline$\varepsilon$ & Tingkat efektivitas vaksin & 0.9 & - & {$[5]$} \\
\hline$b$ & Laju kematian alami & 0,02 & orang & {$[12]$} \\
\hline$c$ & Proporsi vaksinasi & 0.5 & - & Asumsi \\
\hline
\end{tabular}


Pada simulasi numerik ini dilakukan empat skenario yang diharapkan dapat menghasilkan intervensi yang dapat digunakan ke depannya untuk meminimalisir terjadinya penyebaran penyakit rubella. Simulasi dilakukan dengan bantuan software $R$.

Skenario 1 dimaksudkan untuk melihat pengaruh perubahan nilai awal $S(0), V(0), E(0)$, dan $I(0)$ terhadap dinamika populasi pada kondisi $\mathcal{R}_{0}<1$, yang hasilnya dapat dilihat pada Tabel 2.

Tabel 2 Nilai Awal $(S, V, E, I)$ Pada Skenario 1

\begin{tabular}{cccc}
\hline Skenario 1 & Parameter $(\boldsymbol{S}, \boldsymbol{V}, \boldsymbol{E}, \boldsymbol{I})$ & Peluang Wabah & Satuan \\
\hline A & $(5,0.9,0.01,0.01)$ & 0.0695 & Orang (Jutaan) \\
\hline B & $(5,0.7,0.04,0.01)$ & 0.0951 & Orang (Jutaan) \\
\hline C & $(7,0.3,0.01,0.02)$ & 0.1259 & Orang (Jutaan) \\
\hline D & $(7,0.5,0.03,0.02)$ & 0.1421 & Orang (Jutaan) \\
\hline
\end{tabular}

Skenario 2 dimaksudkan untuk melihat pengaruh perubahan nilai perubahan nilai awal $S(0), V(0), E(0)$, dan $I(0)$ untuk parameter $\gamma$ diturunkan dari 365/7 menjadi 3/7 terhadap dinamika populasi, yang hasilnya dapat dilihat pada Tabel 3.

Tabel 3 Nilai Awal $(S, V, E, I)$ Pada Skenario 2

\begin{tabular}{cccc}
\hline Skenario 2 & Parameter $(\boldsymbol{S}, \boldsymbol{V}, \boldsymbol{E}, \boldsymbol{I})$ & Peluang Wabah & Satuan \\
\hline A & $(2,1,1,1)$ & 0.9999 & Orang (Jutaan) \\
\hline B & $(2,1,0.4,0.6)$ & 0.9978 & Orang (Jutaan) \\
\hline C & $(3,2,0.4,0.2)$ & 0.9673 & Orang (Jutaan) \\
\hline D & $(3,2,0.1,0.2)$ & 0.8458 & Orang (Jutaan) \\
\hline
\end{tabular}

Skenario 3 dimaksudkan untuk melihat pengaruh perubahan nilai parameter $\varepsilon$ terhadap dinamika populasi, yang hasilnya dapat dilihat pada Tabel 4 .

Tabel 4 Nilai Tingkat Efektivitas Vaksin Pada Skenario 3

\begin{tabular}{ccccc}
\hline Skenario 3 & Nilai Awal $(\boldsymbol{S}, \boldsymbol{V}, \boldsymbol{E}, \boldsymbol{I})$ & $\boldsymbol{\varepsilon}$ & $\boldsymbol{\mathcal { R }}_{\mathbf{0}}<\mathbf{1}$ & Peluang Wabah \\
\hline $\mathrm{A}$ & $(7,0.5,0.01,0.05)$ & 0.35 & 0.1009 & 0.2828 \\
\hline $\mathrm{B}$ & $(7,0.5,0.01,0.05)$ & 0.55 & 0.0749 & 0.2807 \\
\hline $\mathrm{C}$ & $(7,0.5,0.01,0.05)$ & 0.75 & 0.0625 & 0.2781 \\
\hline $\mathrm{D}$ & $(7,0.5,0.01,0.05)$ & 0.95 & 0.0551 & 0.2749 \\
\hline
\end{tabular}

Skenario 4 dimaksudkan untuk melihat pengaruh perubahan nilai parameter $c$ terhadap dinamika populasi, yang hasilnya dapat dilihat pada Tabel 5.

Tabel 5 Nilai Proporsi Vaksinasi Pada Skenario 4

\begin{tabular}{ccccc}
\hline Skenario 4 & Nilai Awal $(\boldsymbol{S}, \boldsymbol{V}, \boldsymbol{E}, \boldsymbol{I})$ & $\boldsymbol{c}$ & $\boldsymbol{\mathcal { R }}_{\mathbf{0}}<\mathbf{1}$ & Peluang Wabah \\
\hline A & $(7,0.5,0.01,0.05)$ & 0.4 & 0.0694 & 0.2758 \\
\hline B & $(7,0.5,0.01,0.05)$ & 0.6 & 0.0480 & 0.2758 \\
\hline C & $(7,0.5,0.01,0.05)$ & 0.8 & 0.0371 & 0.2758 \\
\hline D & $(7,0.5,0.01,0.05)$ & 1 & 0.0304 & 0.2758 \\
\hline
\end{tabular}

Keterangan: (Gambar 2 sampai dengan Gambar 5).

$$
\begin{array}{ll}
\text { Susceptible } & \text { Vaccinated } \\
\text { Exposed } & \text { Infected }
\end{array}
$$



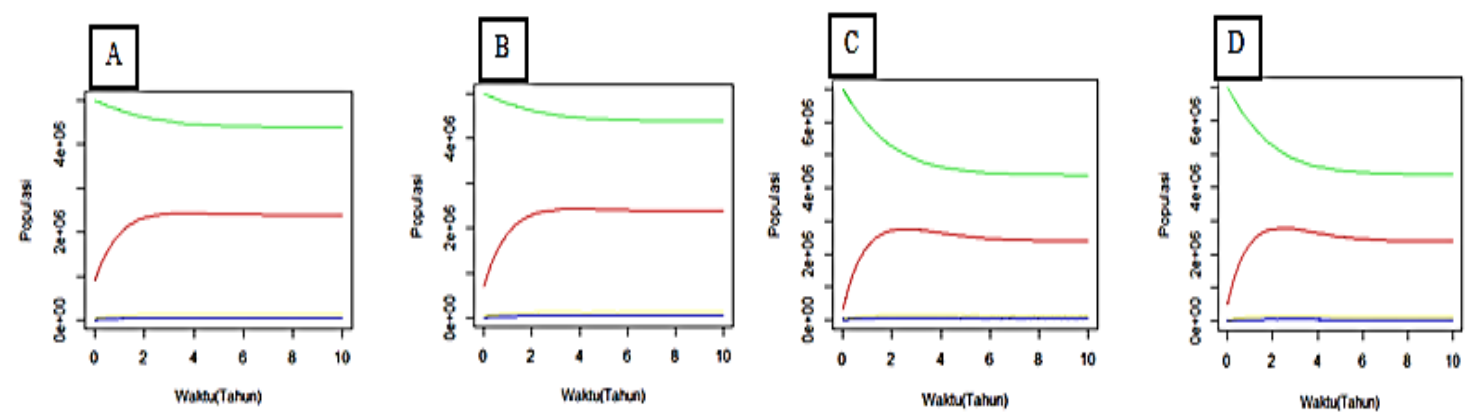

\section{Gambar 2 Sample Path untuk Skenario 1}

Berdasarkan Gambar 2 A, B, C, dan D, dapat dilihat bahwa berapun nilai awal $(S, V, E, I)$ yang diberikan, populasi susceptible, infected, vaccinated dan exposed mengalami penurunan pada sistem. Sehingga penyebaran penyakit rubella berkurang seiring berjalannya waktu.
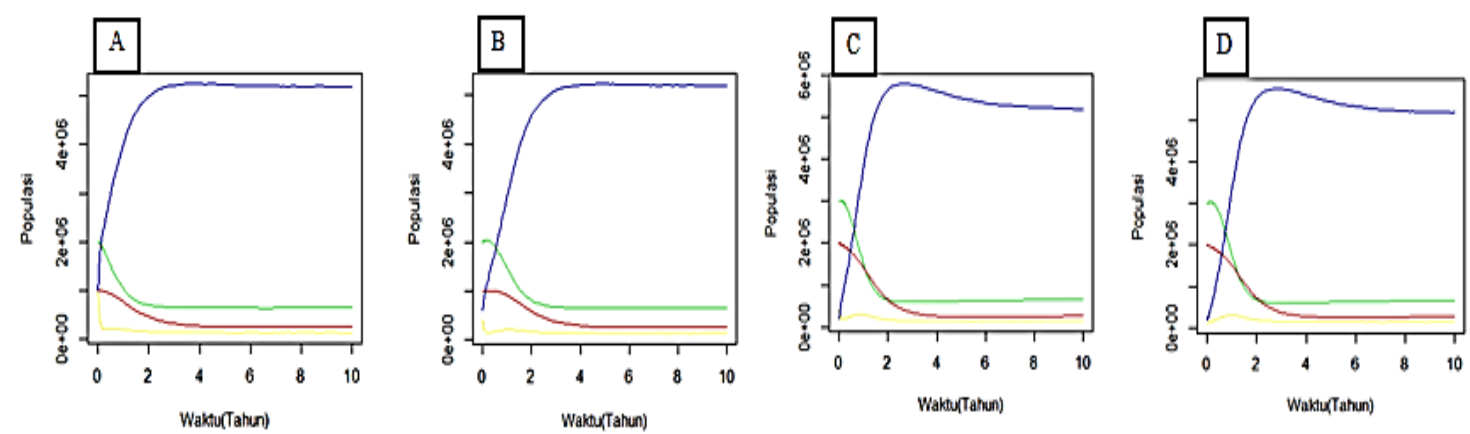

Gambar 3. Sample Path untuk Skenario 2

Berdasarkan Gambar 3 A, B, C, dan D, dapat dilihat bahwa berapun nilai awal $(S, V, E, I)$ dengan memvariasikan nilai parameter $\gamma=365 / 7$ menjadi $3 / 7$ yang diberikan, populasi infected mengalami peningkatan pada sistem. Sehingga penyebaran penyakit rubella membutuhkan waktu yang lama untuk penyembuhan.
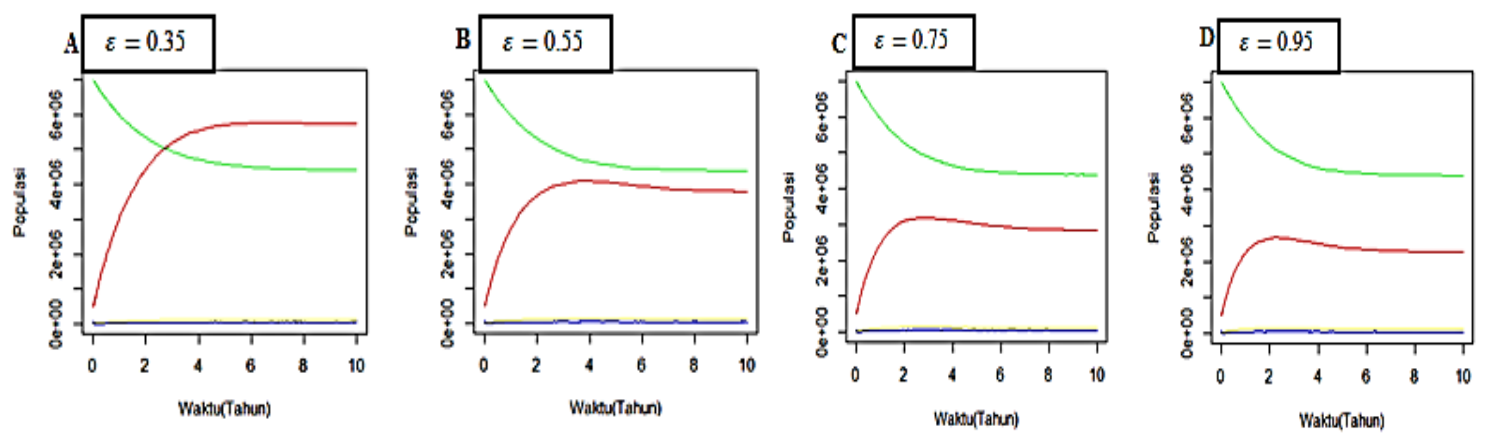

Gambar 4 Sample Path untuk Skenario 3

Berdasarkan Gambar 4 A, B, C, dan D, dapat dilihat bahwa dengan memvariasikan nilai tingkat efektivitas vaksin yang diberikan semakin tinggi, populasi susceptible, vaccintaed, exposed dan infected mengalami penurunan pada sistem. Sehingga penyebaran penyakit rubella akan berkurang seiring berjalannya waktu. 

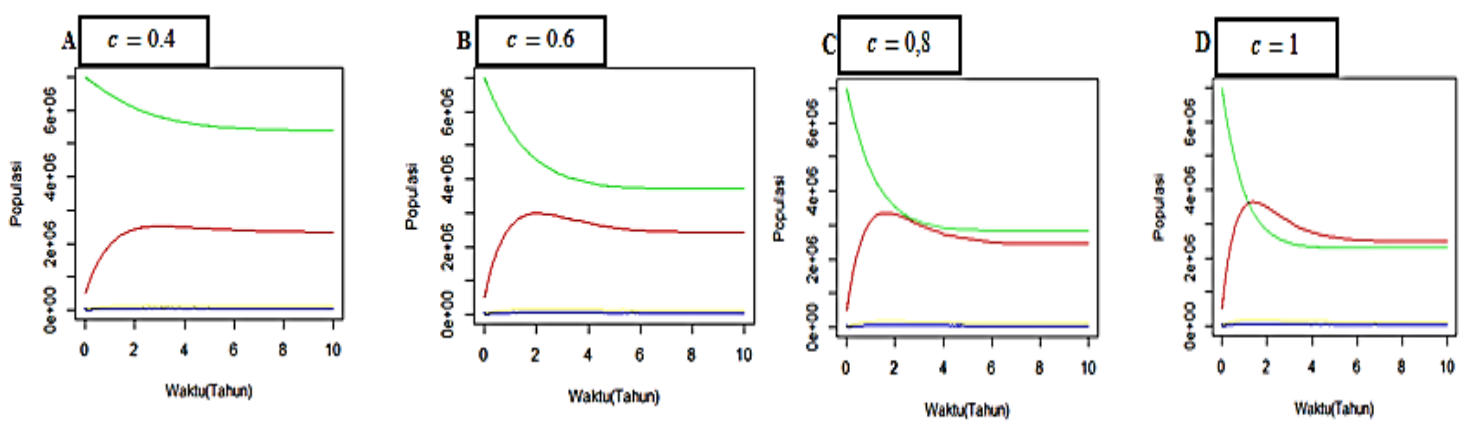

Gambar 5 Sample Path untuk Skenario 4

Berdasarkan Gambar 5 A, B, C, dan D, dapat dilihat bahwa dengan memvariasikan nilai proporsi vaksinasi yang diberikan semakin tinggi, populasi susceptible, vaccintaed, exposed dan infected mengalami penurunan pada sistem. Sehingga penyebaran penyakit rubella akan berkurang seiring berjalannya waktu. Seperti dapat dilihat pada Tabel 2 - Tabel 3 dan Gambar 2 - Gambar 3 bahwa perubahan nilai awal mempengaruhi terjadinya peluang wabah. Dengan menurunnya laju sembuh hingga lebih dari 100 kali, menyebabkan peluang wabah meningkat mendekati 1. Pada gambar tersebut juga dapat dilihat bahwa wabah penyakit Rubella menghilang sekitar 2-4 tahun ke depan. Sedangkan pada Tabel 4 - Tabel 5 dan Gambar 4 - Gambar 5 dapat dilihat bahwa pengaruh dari perubahan efektivitas vaksin dan laju vasinasi terhadap nilai $R_{0}$. Semakin tinggi tingkat efektivitas vaksin dan laju vaksinasi dapat menurunkan nilai $R_{0}$ dengan nilai peluang wabah yang cukup kecil. Dari Gambar 4 dan Gambar 5 juga dapat dilihat bahwa pada tahun pertama wabah penyakit Rubella sudah menghilang.

\section{KESIMPULAN}

Pada penelitian ini dapat diperoleh beberapa kesimpulan, yaitu:

1. Model SIR Beraud (2017) dan model SVIR Saito et.al (2018) menjadi model SVEIR dengan CTMC mampu menjelaskan dinamika penyakit Rubella secara stokastik.

2. Berdasarkan model tersebut dengan menentukan peluang transisi dapat diperoleh grafik dinamika penyebaran penyakit pada kondisi waktu tertentu.

3. Berdasarkan model tersebut, bahwa hasil numerik yang dilakuukan pada skenario I, memperoleh kondisi $\mathcal{R}_{0}=0.0567<1$ dan peluang rata-rata wabah 0.4326 Pada skenario II, dengan memvariasikan nilai parameter $\gamma=365 / 7$ menjadi $\gamma=3 / 7$ sehingga diperoleh $\mathcal{R}_{0}=6.4480>1$ dan diperoleh peluang rata-rata wabah 0.9527 . Pada skenario III, dengan memvariasikan parameter $\varepsilon$, diperoleh nilai rata-rata $\mathcal{R}_{0}=0.0734<1$ dan peluang rata-rata wabah 0.2791 . Pada skenario IV, dengan memvariasikan nilai parameter $c$, sehingga diperoleh nilai rata-rata $\mathcal{R}_{0}=0.0462<1$ dan diperoleh peluang wabah 0.2758 .

4. Dari hasil simulasi diperoleh bahwa semakin dipercepat laju masa penjangkitan $(\gamma)$ menghasilkan penyebaran penyakit semakin terus menerus mewabah. Laju efektivitas vaksin $(\varepsilon)$ dan laju vaksin $(c)$ yang diberikan semakin tinggi menghasilkan berkurangnya penyebaran penyakit Rubella, populasi terinfeksi dan terekspos semakin cepat berkurang.

\section{DAFTAR PUSTAKA}

[1] M. S. Pagonendji, I. Gouandjika-vasilache, A. Le Faou, E. Charpentier, E. Duval, and M. H. Judith, "Journal Pre-proof,” pp. 2015-2016, 2021, doi: 10.1016/j.ijid.2021.08.050.

[2] World Health Organiztion, "Rubella." https://www.who.int/news-room/fact-sheets/detail/rubella.

[3] M. K. Patel et al., "The epidemiology of rubella, 2007-18: an ecological analysis of surveillance data," Lancet Glob. Heal., vol. 8, no. 11, pp. e1399-e1407, 2020, doi: 10.1016/S2214-109X(20)30320-X.

[4] Rokom, "Kemenkes Utamakan Pencegahan dan Perlindungan Kesehatan Bagi Generasi Penerus Bangsa," Jakarta, 2018. https://sehatnegeriku.kemkes.go.id/baca/umum/20180918/3827958/kemenkes-utamakan-pencegahan-dan-perlindungankesehatan-bagi-generasi-penerus-bangsa/.

[5] M. M. Saito, K. Ejima, R. Kinoshita, and H. Nishiura, "Assessing the effectiveness and cost-benefit of test-and-vaccinate policy for supplementary vaccination against rubella with limited doses," Int. J. Environ. Res. Public Health, vol. 15, no. 4, 2018, doi: 10.3390/ijerph15040572.

[6] E. Stanley A. Plotkin, Vaccines, 4th ed. USA: Elsevier Inc., 2004. 
[7] S. M. Ross, Continuous-Time Markov Chains. 2019.

[8] Allen LJS, An Introduction to Stochastis Processses with Application to Biology. USA: Pearson Education, INC, 2003.

[9] L. J. S. Allen, An Introduction to Stochastic Processes with Applications to Biology, 2nd ed. Lubbock, Texas, USA: Taylor \& Francis Group, 2010.

[10] P. Van Den Driessche and J. Watmough, "Reproduction numbers and sub-threshold endemic equilibria for compartmental models of disease transmission," Math. Biosci., vol. 180, no. 1-2, pp. 29-48, 2002, doi: 10.1016/S0025-5564(02)00108-6.

[11] Tu PNV, Dynamical System: An Introduction with Application in Economics and Biology. Heidelberg (DE): Springer-Verlag, 1994.

[12] G. Béraud, "Mathematical models and vaccination strategies," Vaccine, vol. 36, no. 36, pp. 5366-5372, 2018, doi: 10.1016/j.vaccine.2017.10.014.

[13] L. J. S. Allen and G. E. Lahodny, "Extinction thresholds in deterministic and stochastic epidemic models," J. Biol. Dyn., vol. 6, no. 2, pp. 590-611, 2012, doi: 10.1080/17513758.2012.665502.

[14] S. Djauzi, Pedoman Imunisasi Pada Orang Dewasa 2017, 4th ed. Jakarta Pusat: Interna Publishing, 2017.

[15] Hamborsky $\mathrm{J}$ et.al, Epidemiology and prevention of vaccine-preventable diseases. Washington D.C: Public Health Foundation, 2017. 